\title{
ORGANIZATION OF GOODS DELIVERY IN E-COMMERCE
}

\section{MACIEJ CZAPLEWSKI}

University of Szczecin, POLAND

e-mail: maciej.czaplewski@wzieu.pl

\author{
\begin{tabular}{l|l} 
RECEIVED & 12 May 2018
\end{tabular} \\ ACCEPTED 22 September 2018 \\ JEL \\ CLASSIFICATION \\ L81, 032
}

KEYWORDS e-commerce, logistics, goods delivery

ABSTRACT Customers using e-commerce expect fast delivery of ordered goods, including quick delivery of tangible goods. The fulfillment of this postulate requires proper organization of delivery of tangible goods purchased online and underlines the importance of the delivery phase in the e-commerce transaction process.

The main aim of the article is to describe and to some extent also analyze the role of an adequate delivery phase organization in order to ensure a smooth e-commerce transaction process. In consequence the article assumes a hypothesis: ensuring an efficient organization of the delivery phase of material goods acquired online is an important factor supporting the rapid pace of e-commerce development.

In order to achieve the assumed goal and prove the adopted hypothesis, the author presents issues connected with the essence of e-commerce, the role of transport and logistics in the e-commerce value creation chain and pursued delivery solutions in e-commerce, including the directions of their improvement and the observed co-evolution of e-commerce development and transport as well as used logistics solutions.

\section{Introduction}

The subject of e-commerce transactions may be:

- digital goods, for which the entire transaction process can be carried out using electronic channels,

- tangible goods that require delivery with traditional means of transport. 
Customers using e-commerce expect fast delivery of ordered goods, including quick delivery of tangible goods. The fulfillment of this postulate requires proper organization of delivery of tangible goods purchased online and underlines the importance of the delivery phase in the e-commerce transaction process.

The aim of the article is to present the role of proper organization of the delivery phase in ensuring a smooth e-commerce transaction process.

The article assumes the following hypothesis:

- ensuring an efficient organization of the delivery phase of material goods acquired online is an important factor supporting the rapid pace of e-commerce development.

In order to achieve the assumed goal and prove the adopted hypothesis, the article presents:

- the essence of e-commerce,

- the role of transport and logistics in the e-commerce value creation chain,

- pursued delivery solutions in e-commerce, including the directions of their improvement and the observed co-evolution of e-commerce development and transport as well as used logistics solutions.

\section{The essence of e-commerce}

The wide use of the virtual market space in business leads to the creation of e-business. So far, one commonly accepted definition of e-business has not been developed. M. Norris and S. West assume that e-business covers "all problems related to the purchase and sale of goods and services available through the network" (Norris, West, 2001, p. 16). The definition of e-business presented by IBM (No year indicated, p. 28) is more extensive, according to which e-business is a "safe, integrated and flexible approach to providing various business values through the combination of systems and processes leading to proper business operations using the Internet technology". Even more detailed approach indicates that in the context of e-business, Internet technology is used in contacts with clients, within the enterprise itself (via Intranet) and in contacts with suppliers (via Extranet) (Choi, Stahl, Whinston, 1997, p. 12). It should be emphasized that the rapid development of the Internet has led to the emergence of new sectors of the economy, either directly or indirectly related to the functioning of the network (Drab-Kurowska, 2013, pp. 501-511).

A graphic depiction of this system and its use to distinguish two concepts: e-business and e-commerce, clearly presented P. Staehler. This is presented in Figure 1.

The approach shown in Figure 1 shows that companies utilizing e-business use Internet technology in three basic relationships:

- with clients (Internet),

- with business partners (Extranet),

- within the company (Intranet).

This figure also shows that e-business is a broader concept than e-commerce, the essence of which boils down to the use of Internet technology in the relations between the company and customers.

The concept of e-commerce is also defined in various ways. According to B. Gregor and M. Stawiszyński, e-commerce is "the process of selling and buying products and services, and thus entering into commercial transactions using electronic means, conducted via the Internet (where often traditional tools like fax or telephone are also helpful)" (Gregor, Stawiszyński, 2002, p. 79). L. Mueller-Hagedorn (2000, pp. 49-57) claims that 
e-commerce involves transactions of paid exchange of goods carried out between independent entities using interactive electronic media, such as the Internet.

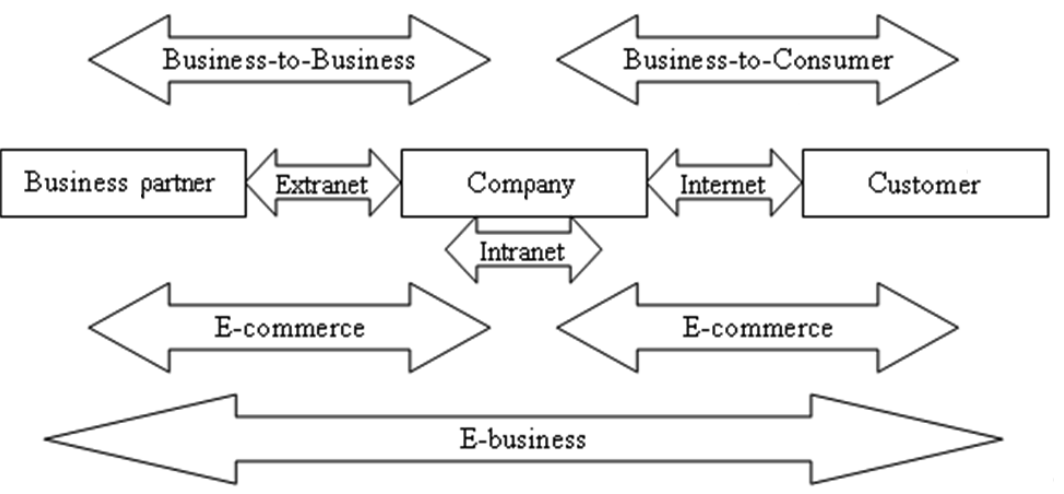

Figure 1. E-business and its basic relations

Source: Stähler (2006), p. 65.

Florian Gierke (2005, pp. 4-78) defines e-commerce as the beginning, negotiation and implementation of commercial activities using the Internet network. In turn, K. Frank, J. Kerp and F. Globisch (2001, pp. 16-114) point to the fact that e-commerce can be both - part of an e-business system focused on distribution as well as an independent solution.

Making an attempt to generalize the characterization of e-commerce, according to the author, the following three features should be emphasized:

- e-commerce is based on the use of interactive internet technology in the processes of buying and selling goods and services,

- is a part of e-business, including transactions between the company and buyers of its products,

- Internet technology can be used to implement all phases of the transaction process, and the minimum condition for its recognition as e-commerce transaction is the use of the Internet in the implementation of the basic phases of this process, i.e. during negotiations and arrangements (Dobosz, 2012, p. 1).

\section{The role of transport and logistics in e-commerce value creation chain}

Dynamic development of e-commerce, including the growing demand for e-commerce services as well as increased competition between e-sellers as well as between electronic and traditional trade, encourages e-sellers to find ways at best to adapt to the requirements of e-buyers. This involves the need to organize non-complex, transparent chains of value creation, guaranteeing their speed and efficiency. This requires:

- possible minimization of the number of necessary processes carried out between e-sellers and e-buyers,

- ensuring strong consistency of these processes.

To achieve these goals, one can use a procedure that goes down to (Osterloh, Frost, 2006, p. 27): 
- separation of processes of basic and secondary importance. This division is usually made on the base of two criteria:

- the importance processes from the customer's needs point of view,

- the possibilities of distinguishing from the competition;

- separation of basic functions as part of the processes, which must be implemented in the event of a transaction. An important function in this respect is the logistic connection of the place where the purchased goods are located with the place to which they have to be delivered. K. Iwińska-Knop (2004, p. 11) states that distribution is currently one of the most important factors determining the company's competitive advantage.

The actions taken in the first step primarily lead to the prominence of sales processes and marketing activities used to support sales. On the other hand, actions taken in the second step allow to emphasize the role of logistics in the chain of e-commerce value chain creation. This role is primarily indicated by a direct link between the classic marketing concept of $4 \mathrm{P}$ and logistics activities, as shown in Figure 2.

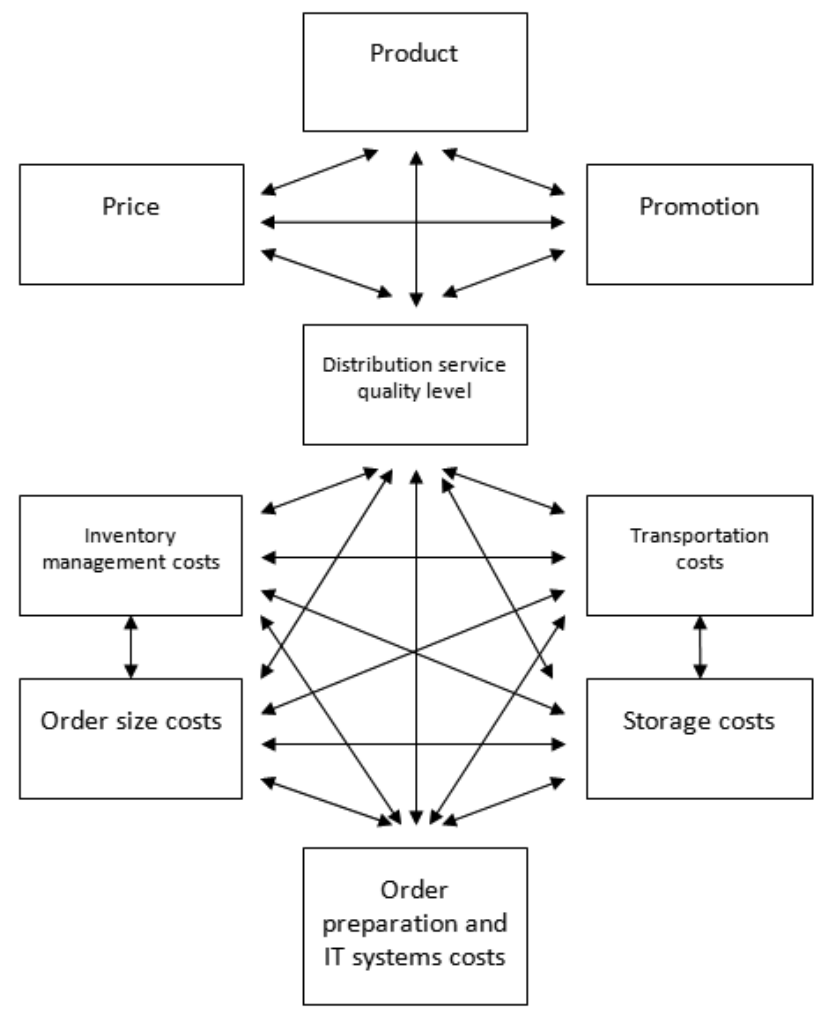

Figure 2. Linkage between marketing and logistics activities

Source: Stock, Lambert (2001), p. 86. 
The importance of logistics in the e-commerce value creation chain is primarily connected with the need to rationally link the place where ordered via the Internet goods are located with the place to which they have to be delivered. In graphic terms, this is shown in Figure 3.
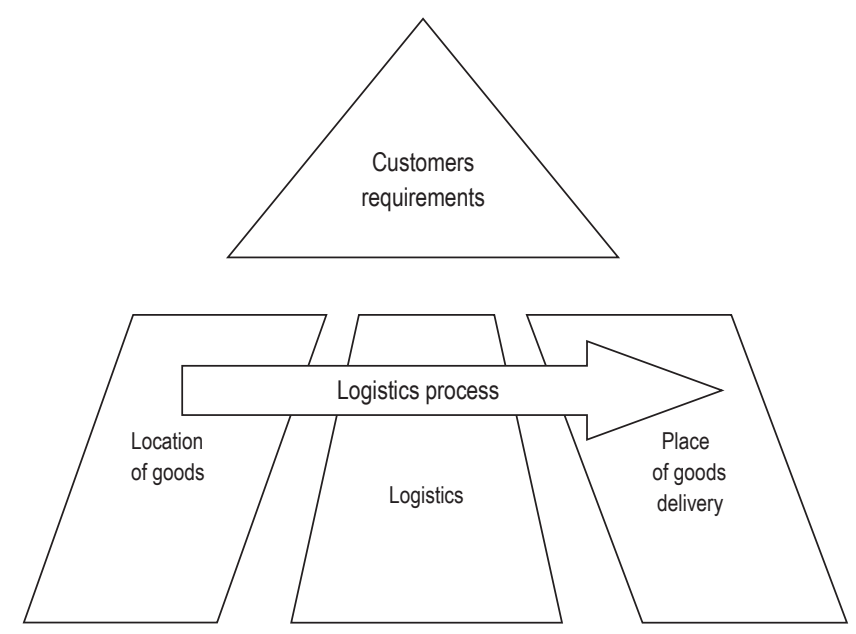

Figure 3. Logistics as an instrument of rational binding of the place where the goods are located with the place where they have to be delivered

Source: own elaboration with the use of: Osterloh, Frost (2006), p. 32.

Considering the interest of customers in the efficient delivery of goods ordered online, the e-sellers must make every effort to ensure effective and efficient delivery of goods to the e-buyers. Thanks to the e-commerce properties, the delivery processes are characterized by a high level of electronic channels use, and the technical progress and the decrease in the costs of its use is conducive to further improvement of this level (Cellary, Stryjowski, Remesz, Toboła, 2002, p. 49). This promotes the creation of electronic supply chains (Stryjkowski, Cellary, 2006, p. 45). Supply chains, oriented to customer needs and satisfying these needs by combining business processes with the increasing use of virtual networks, A. Harrison and R. Hoek (2010, p. 272) described as agile supply chains.

An important feature that distinguishes supply chains that use electronic networks from traditional chains is the ability to separate information flow streams from goods flow streams. Information can be treated as an element of competitive advantage, and at the same time a source of this advantage. It is important to constantly acquire, process and use more and more information in less and less time (Budziewicz-Guźlecka, 2013, p. 88). Subsequently this creates the possibility of quick and adequate response to changes in demand for specific final goods. It also facilitates quick response to changes in the volume of orders for a given good and adapting to these changes delivery solutions.

Special opportunities in this regard occur in e-commerce transactions regarding the acquisition of digital goods, where the value creation chain is related to:

- lower production costs of these goods,

- the possibility of skipping the costs of packaging and traditional transport. 
Despite a special impact of modern information and communication technologies, in particular the Internet, on rationalizing logistic processes servicing e-commerce transactions, which are digital goods, these technologies also significantly support the rationalization of logistics processes serving the supply of tangible goods. In relation to these transactions, the positive impact of modern information and communication technologies boils down to:

- promoting flexible cooperation between e-sellers and e-buyers, allowing a better coordination of the delivery time of numerous small shipments and their grouping in logically combined collective loads,

- limiting incorrectly organized and implemented delivery processes due to continuous and efficient flow of information between e-sellers, e-buyers and the carrier.

\section{Applied delivery solutions in e-commerce}

The area of using logistics and transport in e-commerce is closely related to the scope of Internet use in individual transactions. This scope is primarily dependent on the type of goods being the subject of a particular transaction. In the situation when all transaction phases are implemented using electronic channels, there is no need to use physical logistics and transport processes. This is possible only when the subject of the transaction is in a form of a digital good. When the subject matter are tangible goods, e-sellers need to apply logistic solutions that take into account the necessity to physically prepare goods for transport, appropriate linking of individual shipments that allow rational use of transport means and the efficient delivery of individual shipments to recipients.

The general approach to the use of logistics in e-commerce is presented in Table 1.

Tahle 1. Basic logistics solutions in e-commerce

\begin{tabular}{lll}
\hline $\begin{array}{l}\text { Scope of using the Internet in e-commerce } \\
\text { transactions }\end{array}$ & \multicolumn{1}{c}{ Transaction characteristics } & Logistics requirements \\
\hline In the pre-sale and sales stages & $\begin{array}{l}\text { use of electronic channels in the information } \\
\text { phase of order recognition }\end{array}$ & $\begin{array}{l}\text { the need to organize physical processes } \\
\text { to prepare a good for transportation, combining } \\
\text { individual shipments in consignment parties and } \\
\text { delivering individual parcels to recipients }\end{array}$ \\
\hline $\begin{array}{l}\text { In the pre-sale, after-sales and after-sales } \\
\text { phases }\end{array}$ & $\begin{array}{l}\text { use of electronic channels in the phase } \\
\text { of information orders, delivery and delivery } \\
\text { charges and in the after-sales phase (eg. } \\
\text { complaints) recognition }\end{array}$ & $\begin{array}{l}\text { no need to use traditional transport processes } \\
\text { and logistic organization of these processes. } \\
\text { Possibility to limit to e-logistics, using only } \\
\text { electronic media in organizing the way of carrying } \\
\text { out e-commerce transactions }\end{array}$ \\
\hline
\end{tabular}

Source: own elaboration.

E-commerce transactions, the subject of which are tangible goods in a natural way involve engaging logistic solutions that require consideration of traditional warehouse, cargo and transport processes.

The general approach to the structure of delivery channels used in e-commerce is shown in Figure 4.

In the organization of tangible goods supply, the following strategies are primarily used:

- on-time delivery (just-in-time) - allowing to limit inventory, rationalize costs and improve operational efficiency,

- quick response - aimed at improving the relationship between the level of costs and the quality of delivery service by fast transfer and exchange of information on demand and stock levels, 
- effective customer response - aimed at effectively satisfying the client's needs while maintaining the lowest possible stock of inventory by using modern information and communication technologies in contacts between the participants of the logistics chain (eg. between the e-seller, the cargo dispatcher and the carrier).

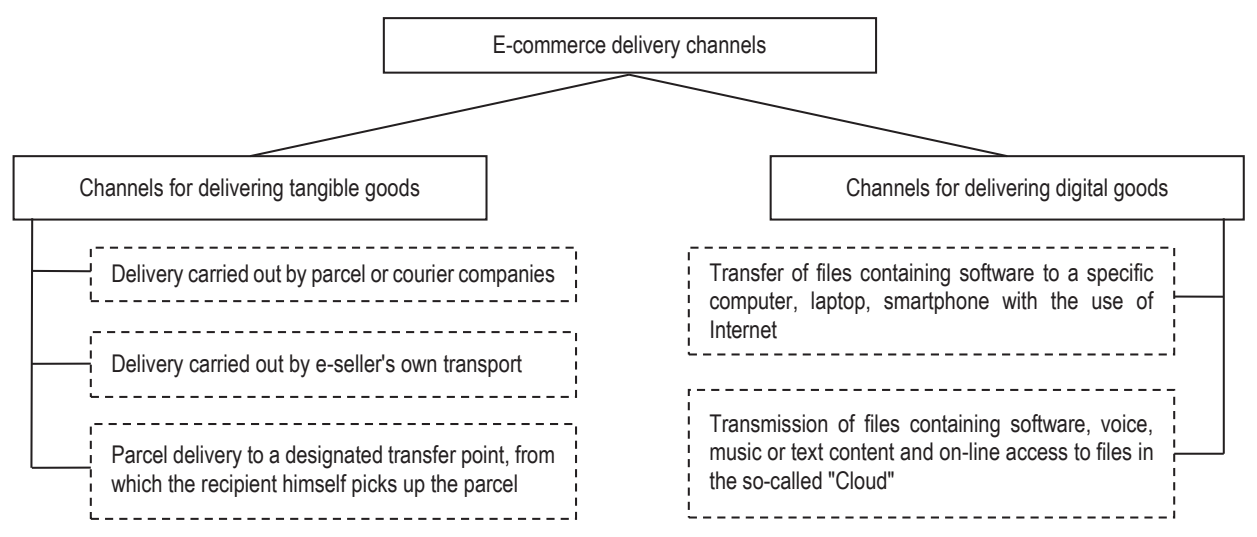

Figure 4. Basic delivery channels used in e-commerce

Source: own elaboration.

The significance of the logistics strategies mentioned above results in particular from the fact that they have contributed to giving logistics the role of one of the central assets for efficient organization of the entire transaction process, including fulfilling the function of coordinating and controlling the supply chain.

Expanding and improving the system of sales channels used by Internet companies, allows to talk about a certain e-commerce co-evolution and logistics solutions used in it. Co-evolution is due to the fact that:

- growing e-commerce and high requirements set by e-commerce users in the field of fast delivery of numerous small shipments to spatially distributed individual customers, have set new requirements for delivery systems,

- meeting these requirements was associated with the need to improve distribution systems.

\section{Conclusions}

The basis of e-commerce development is the use of the Internet potential in order to conduct sales activities. However, it should be noted that the subject of e-commerce transactions are not only digital goods, but also (or even at most) tangible goods. In the case of such goods, their delivery must take place using traditional transport services, in which transport and logistics operators specialize. This means the dependence of the implementation of many e-commerce transactions on the use of traditional transport and logistics solutions.

The search for transport and logistics solutions that take full account of the needs of e-commerce is based on: developing logistic models and on using the Internet's potential. 
Such activities allow to rationalize the demand of e-commerce for transport and logistics services implemented by specialized companies. This improves the quality of transport services of tangible goods purchased over the Internet. An important positive consequence of improving the quality of deliveries service of goods purchased online should be the further development of e-commerce, resulting in, among others, an increase in demand for transport and logistics services related to the service of goods purchased via the Internet.

\section{References}

Budziewicz-Guźlecka, A. (2013). Wiedza i kapitał ludzki czynnikiem rozwoju przemysłów kreatywnych. In: J. Stankiewicz, Z. Binek, S. Kotylak (eds.), Przemysł kreatywny - Ekonomia na styku kultury i biznesu (pp. 84-99). Zielona Góra: Wydawnictwo MAjUS.

Cellary, W., Stryjowski, S., Remesz, L., Toboła, M. (2002). Ewolucja łańcucha dostaw w gospodarce elektronicznej. Warszawa: PWE.

Choi, S.-Y., Stahl, D.O., Whinston, A.B. (1997). The Economics of Electronic Commerce. Indianapolis: Macmillan Technical Publishing.

Dobosz, K. (2012). Handel elektroniczny. Warszawa: Wydawnictwo Polsko-Japońskiej Wyższej Szkoły Technik Komputerowych.

Drab-Kurowska, A. (2013). Polityka konkurencji na rynku e-commerce. Zeszyty Naukowe Uniwersytetu Szczecińskiego. Ekonomiczne Problemy Usług, 104/1.

Frank, K., Kerp, J., Globisch, F. (2001). Die Veränderung von traditionellen Wertschöpfungsketten zu neuen Geschäftsmodellen durch eBusiness oder eCommerce. Aachen: Shaker Verlag.

Gierke, F. (2005). Kundenorientierung im E-Commerce-Prozess - Ein ereignisorientierter Ansatz. In: B. Gregor, M. Stawiszyński (eds.), e-Commerce. Bydgoszcz-Łódź: Oficyna Wydawnicza Branta.

Strategisches Management, Bd. 25. Hamburg: Verlag Dr. Kovač.

Harrison, A., Hoek, R. (2010). Zarządzanie logistyką. Warszawa: PWE.

IBM (No year indicated). Dictionary of IBM \& computing terminology. Retrieved from: https://www-03.ibm.com/ibm/history/documents/ pdf/glossary.pdf (10.03.2018).

Iwińska-Knop, K. (2004). Kanały rynku we współczesnej gospodarce. Łódź: Wydawnictwo UŁ.

Mueller-Hagedorn, L. (2000). Zum Abgrenzung von E-Commerce. Definitorische Anmerkungen. In: Zukunftsperspektiven des E-Commerce im Handel. Frankfurt am Main: Deutscher Fachverlag.

Norris, M., West, M. (2001). E-biznes. Warszawa: Wydawnictwa Komunikacji i Łączności.

Osterloh, M., Frost, J. (2006). Prozessmanagement als Kernkompetenz. Wiesbaden: Gabler Verlag.

Stähler, P. (2006). Geschäftsmodelle in der digitalen Ökonomie: Merkmale, Strategien und Auswirkungen. Presented after I. Hausladen, Geschäftsprozessgestaltung von E-Maintenance-Lösungen von Unternehmen. Frankfurt am Main: Peter Lang.

Stock, J.R., Lambert, D.M. (2001). Strategic Logistics Management. New York: McGraw-Hill Book Co.

Stryjowski, S., Cellary, W. (2006). Elektroniczne łańcuchy dostaw. Logistyka, 1.

Cite this apticle aS: Czaplewski, M. (2018). Organization of goods delivery in e-commerce. European Journal of Service Management, 3 (27/1), 39-46. DOI: 10.18276/ejsm.2018.27/1-05. 